\title{
PRINCIPLES TO PRACTICE: INDICATORS FOR MEASURING EVENT GOVERNANCE PERFORMANCE
}

\author{
MICHELLE WHITFORD,* GIANG THI PHI,* AND DIANNE DREDGE† \\ *Department of Tourism, Sport and Hotel Management, \\ Griffith Business School, Griffith University, Brisbane, Australia \\ †Department of Culture and Global Studies, Aalborg University, Copenhagen, Denmark
}

\begin{abstract}
Governments are increasingly involved in public-private partnerships to attract, support, and/or stage events. This involvement often leads to governments becoming embroiled in highly politicized battles that focus on issues including community benefit, mitigation of impacts, transparency in decision making, and lack of consultation before, during, and after the event. To date, minimal attention has been paid to the public-private governance arrangements underpinning events. This article seeks to address this gap by presenting a set of indicators that can be operationalized to improve event governance. The article proposes an indicators framework for event governance designed to reflect the event policy-making process. It contributes to the literature by facilitating greater understanding of the significance and influence of event governance indicators. Future application of the framework in research and practice will provide governments with a new management tool, which will enhance democratic decision making and facilitate competitive advantage in a globalized marketplace.
\end{abstract}

Key words: Events; Governance; Indicators; Decision making

\section{Introduction}

Globally, governments at all levels continue to support and/or stage events, citing the multitude of benefits that can be derived from staging events. In the process, large amounts of public funds are directed towards meeting the objectives of private event organizations. Not surprisingly, many governments have been criticized for their involvement in events, particularly over the last two decades (Gamage \& Higgs, 1996; Lowes, 2004; Warren, 2002). Much of this criticism is derived from governments' zealous pursuit of, and emphasis on, economic development objectives in contrast to social, cultural, and environmental objectives; superficial public consultation practices that are perceived to marginalize community interests (Fredline \& Faulkner, 2001); and the increased use of statutory 
corporations and private companies (created by governments to bid for and stage events), which increasingly blur lines between public and private interests and serve to distance government from direct responsibility for negative impacts and failures (Dredge \& Whitford, 2011; Stokes \& Jago, 2007). Despite these criticisms, governments continue to promote the benefits of events, and in the process often become embroiled in highly politicized battles. The governance arrangements (or lack thereof) associated with an event can be a key source of these conflicts, yet to date there has been little critical attention on such issues.

For the purpose of this article, governance is the act of governing: it refers to the structures and processes through which policy actors interact with each other to pursue individual and mutual interests, and the level and type of steering that governments undertake within these arrangements. The term "governance" captures the idea that governing is increasingly shaped by networks of public and private actors and that power and authority are shared (Dredge \& Pforr, 2008; Ladeur, 2004; Marsh, 2002). Some argue that it opens up the opportunity for more democratic and accessible forms of policy making (Agere, 2000; Good Governance Advisory Group, 2004). Others note that issues are identified, priorities are assigned, and decisions are made in a range of formal and informal spaces that extend well beyond traditional government structures and processes. As a result of individuals and groups seeking to lobby, discuss, and decide issues in informal settings, criticisms have been forthcoming stating that the interest-driven politics underpinning the governance processes lack transparency and accountability (D. Burns, 2000; Klijn \& Skelcher, 2007). These issues are particularly pertinent in understanding the conflicts around the planning and staging of events, where governments are often seen to dismiss local community interests in favor of perceived economic benefits to a broader public interest (Foley, McGillivray, \& McPherson, 2009; Getz, 2009; Stokes, 2008).

This article seeks to address issues associated with the governance of events by developing a set of indicators that can be used to evaluate the effectiveness of event governance. There have been several attempts at identifying sustainability indicators for events, with a range of environmental, social, and financial/economic indicators proposed (see Griffin, 2009; Harris, 2005; Yaghmour, 2008). Yet little to no research has been undertaken focusing on the governance dimension. As a result of a lack of literature in this area, we have had to build up a theoretical base in the knowledge that this work will be applied in the future. Therefore, the contribution of this conceptual article is to add a governance dimension to these indicators, and in doing so, provide a discussion to the existing literature with a "quadruple bottom line" of sustainable event indicators. In addressing the above aim, two objectives frame this article: First, the article explores the challenges and opportunities associated with event governance, which will in turn form the basis of the indicators framework. Second, the article presents a framework of indicators that can be used to evaluate event governance. The contribution of the indicators framework is to improve event governance. To date, little to no attention has been paid to governance in the context of events (Yaghmour, 2008). Even less attention has been given to developing indicators or standards of auditing that can help inform the design and development of event governance arrangements and can help to monitor shifts over time (Bovaird \& Löffler, 2003).

\section{Events, Governance, and Steering}

Over the last three decades, globalization and neoliberal forms of public management have brought significant change in governments' roles and responsibilities (e.g., Gibson-Graham, 2006; Hirst, 2000; Marsh, 2002; Pierre, 2000; Rhodes, 1997). Commentators observe that globalization, as a driver of economic development and consumer-driven growth, has brought with it political and social benefits for governments and corporate interests in Western liberal democratic countries (i.e., increased living standards and disposable income translate into happy voters that reinforce the status quo). As a result, corporate power has continued to strengthen; the private sector has become increasingly intertwined with government and in some sectors has increasingly captured government's policy-making functions (Klijn \& Skelcher, 2007; Sørensen \& Torfing, 2005). Giddens (1998) observes that civil society has become increasingly marginalized and disenfranchised with government and that communities 
needed to engage more directly and take a greater role in making change happen (Giddens, 2000). This movement towards greater democratic participation and community empowerment has become known as "the third way" political movement, and more recently has been given credence in the UK Cameron Labor Government’s “Big Society.” These trends are clearly evident in the wider tourism literature, where concerns have been consistently raised about the influence of corporate power, the priority given to private sector interests, and increasing calls for community empowerment (HigginsDesboilles, 2006; Mowforth \& Munt, 2003). Within this context, the role of government and particularly its capacity for directing and shaping change has been questioned. Governing increasingly involves deliberations among multiple actors, and power to make and implement decisions becomes less dependent upon the authority of the state (Crozier, 2008). Some liken this shift in the role of the state from one of government "rowing" to societal steering and coordination (Crozier, 2008; McSweeney, 2006; Savas, 1993).

Within the broader literature, governance has been explored as a theoretical construct (B. Bramwell, 2011; Hall, 2011), as a set of structures, processes, and operational characteristics (Beaumont \& Dredge, 2010; B. Bramwell \& Pomfret, 2007; Eagles, Havitz, McCutcheon, Buteau-Duitschaever, \& Glover, 2010), as a set of principles (UK Department for Communities and Local Government, 2006), and its implications on issues such as sustainability (Dinica, 2009; Duffy, 2006), public interest, and democracy have also been explored (Dredge \& Pforr, 2008; Dredge \& Whitford, 2011). Although this research yields important insights into a range of dimensions, including the issues and opportunities associated with various governance structures, power relations, and implications for sustainability, it does not focus on the role of government. Arguably, greater attention is needed on the role of government given increasing criticism that corporate power has increased and slippage in addressing public interest has occurred within these arrangements (Dredge \& Jenkins, 2007).

Within this market-dominated policy-making environment, public officials are increasingly in need of tools, techniques, and instruments that can guide the achievement of desired outcomes as diverse and complex as they might be. It is not surprising then that indicators have growing policy relevance as a source for information gathering that can help to map change, and can be reflected upon in order to inform decision making. According to Hezri and Dovers (2006),

the utility of indicators as a policy tool whose traditional role was to fulfil the instrumental need of rationality must, in the new [governance] reality, enhance "steering," "mapping," and "weaving." "Steering” towards sustainability necessitates multiple, appropriate information flows, for wider communication of sustainability values. (p. 88)

The planning and staging of events is a complex, multisectoral, multilevel, decision-making arena that transcends both public and private spheres. Events involve a multitude of actors (e.g., the host organization, community groups, and volunteers), who play diverse roles in the hosting of events (Getz, 2009; S. Reid \& Arcodia, 2002; Whitford, 2005). Events generally take place in settings that are characterized by a preexisting and highly interdependent social, economic, political, and environmental fabric (Allen, O’Toole, Harris, \& McDonnell, 2001). Depending on the nature, size, and impacts of events, they have the potential to affect policy actors at varying levels quite differently (Stokes, 2006). Furthermore, government, nongovernment, community groups, and individuals often have varying expectations and aspirations about the event, all of which have to be carefully managed (Hede, 2007). Public officials involved in event planning and management confront significant challenges. Not only are they operating in a complex institutional environment and influenced by a range of factors that extend well beyond serving traditional public interests, they also need to act flexibly and entrepreneurially to achieve the outcomes that will please their political masters. In this light, the need for market tools and instruments to help guide or steer the planning and staging of events to achieve desired goals becomes apparent.

To date, studies related to event governance are relatively limited and have tended to be exploratory or descriptive in nature. For instance, there is only a small collection of work exploring the roles of government, state institutions or parastatal agencies, and policy networks (e.g., see Getz \& 
Andersson, 2008; Pugh \& Wood, 2004; Thomas \& Wood, 2004; Weed, 2003, 2006; Whitford, 2004a, 2004b). Studies examining policy and public sector involvement in events include Ali-Knight and Robertson (2004), Whitford (2005), and Stokes and Jago (2007). Other research examines the politics of place marketing and/or event policy and regional development (Dredge et al., 2010; Foley et al., 2009; Gotham, 2002; O'Sullivan \& Jackson, 2002; G. Reid, 2006; Whitford, 2009). These studies highlight a range of issues in event governance and support the earlier observation that the challenge of steering towards mutual benefits for both public and private interests lies in effective governance around the bidding for and staging of events. However, there are limited insights into what are the parameters of effective governance and how it can be measured (Getz, 2008).

\section{General Directions for Evaluating Governance}

Indicators are parameters or values that provide information about or describe a phenomenon and which have some significance, or illuminate issues, beyond the value or indicator itself (Organisation for Economic Co-operation and Development [OECD] Environment Directorate, 2004). Over the last 20 years there has been massive growth in the design and development of indicators, with extensive attention on environmental and sustainability indicators. In the area of governance, the need for indicators has emerged as a result of the increasing importance and influence of nonstate actors in policy and decision making (Hezri \& Dovers, 2006). Indicators not only provide information that can inform decision making, but over time they can highlight shifts taking place in the way government and nongovernment actors are engaging, collaborating, and changing practices, and ultimately, the shift from government to governance. Similarly, Francois (2009) observes that indicators have a threefold role: to inform, to alert, and to enable guidance and action.

Governance indicators can cover a wide range of dimensions relating to the way stakeholders interact, the role of government and nongovernment actors, the nature of collaboration and information sharing, and so on (G. Williams, 2011). Independently, an indicator can provide a small piece of information.
However, together they provide a picture that is greater than the sum of individual indicators illuminating the complexity and (in)effectiveness of governance structures and processes and the roles and actions of stakeholders. Drawing from the wider body of literature, attempts to review governance indicators by Arndt and Oman (2006), A. Williams and Siddique (2008), and United Nations Development Programme (UNDP, 2007) identify an explosion in the production of indicators. For example, a recent count identified 400 separate governance indicators (Arndt \& Oman, 2008, cited in G. Williams, 2011), which is not surprising given the diverse settings and problems to which they have been applied.

The plethora of governance indicators that currently exist are being developed and used by a wide range of policy actors from local to global levels (e.g., government and nongovernment organizations, academic institutions, media, foreign investors). Perhaps the three most well-known initiatives to measure governance are those from the public governance literature, developed by the World Bank, the United Nations University, and the OECD (Maurseth, 2008). A key driver for the development of these indicators has been to measure the effectiveness of relationships and exchanges between international investment organizations (e.g., the World Bank, Inter-American Development Bank, etc.), developing countries, and nongovernmental organizations (NGOs) as the service delivery agencies for aid programs. Yet governance indicators such as these are not always meaningful to the event policy community.

As with any set of indicators, there needs to be a clear purpose for which they are designed and developed. The purpose of developing a set of indicators for event governance is to capture information about the effectiveness of relationships between event stakeholders (e.g., government agencies, nongovernment agencies, community, and the private sector); the characteristics of exchange that take place (e.g., information, resources, etc.); and to assess the capacity for shared decision making in the pursuit of mutual interests and societal goals. The indicators not only have to recognize the need for government accountability, but also the need to protect information that is commercial-in-confidence. Hezri and Dovers (2006) also point out the potential 
misuse and misapplication of indicators, highlighting that they can often be used for propaganda purposes and can distract from the implementation of more coherent evaluations.

\section{Event Governance Indicators}

There have been very few attempts to evaluate governance in the event context despite the growing number of studies examining governance problems as discussed previously. A review of literature found only two recent studies involved indicators relevant to event governance. First, an exploratory study by Harris (2005) sought to identify mechanisms event organizers use to assess their efforts in engaging local communities in public events. The indicators Harris (2005) identified were: (1) community input and feedback facilitation through public meetings; (2) community wide surveys; and (3) informal talkback radio stations. Second, Griffin (2009) took into account certain aspects of governance when he developed indicators for sustainable event management. In particular, such indicators included: (1) the measurement of the level of communication between the event enterprise with local community and local businesses; (2) resident awareness and attitude regarding the event; and (3) the effectiveness of administrative goals, policy, and regulations.

There is little doubt that the paucity of event governance indicators reflects the lack of research undertaken to date on event governance. For too long, the evaluation of events has been limited to assessing (positive) economic benefits despite that the methodologies adopted in such research are increasingly questioned (Dwyer, Forsyth, \& Spurr, 2005). Since the 1980s however, there has been increased interest in sustainability, and consequently, increasing calls for a broader approach to evaluating events (see, e.g., R. Bramwell, 1997; J. P. A. Burns \& Mules, 1986; Faulkner, 1993; Fredline, Raybould, Jago, \& Deery, 2005; Getz, 2000; Ritchie, 1984). R. Bramwell (1997) stated, for instance, that "events should be assessed from the outset in relation to the concept of sustainable development, with key indicators of sustainability being identified and then monitored over a long period" (p. 18). The increasing dominance of this view encouraged the development of the triple bottom line approach to event evaluation (Fredline et al., 2005; Sherwood, 2007). As a result, Sherwood (2007) found that the sociocultural impacts of events were receiving more attention. Interestingly however, the broader sustainable development literature was already moving from a triple to a quadruple bottom line, with governance often proposed as the additional fourth dimension (see, e.g., Suggett \& Goodsir, 2002; Teriman, Yigitcanlar, \& Mayere, 2009). Given the importance of coordination in governments' attempt to steer society towards sustainability goals, there still needs to be more nuanced understandings of the effectiveness and changes in stakeholder roles and relationships and the nature of exchange that takes place.

\section{Selecting Indicators}

The framework for event governance indicators developed in this article provides a pathway to identify and design measures that can be used to generate information about event governance. At the outset, it is important to consider the intended use of the indicator itself and its overall position and complementarities within the entire set of indicators. It is also important to recognize that there is a range of factors that needs to be taken into account including the heterogeneous nature of stakeholders and event agencies, and the various levels of expertise, resources, and capacities available to undertake data collection and assessment. For instance, a comprehensive and detailed set of indicators might be theoretically sound, but impractical because of the capacity of users to collect data, the availability of data, and so on. For this reason, the indicators chosen must reflect a balance between being comprehensive, targeted, and practical. Table 1 identifies a range of principles identified from the literature that guides the selection of indicators.

\section{Data Collection}

A range of factors often shapes what data are useful and relatively easy and cost effective to obtain. Issues such as time coverage, sampling, the nature of questions, and collection methods (e.g., interview, surveys, and/or observations) must be taken into account during the data collection process. Data should be collected at various stages (i.e., planning, implementation, and evaluation) and, to ensure data 
Table 1

Principles for the Selection of Indicators

\begin{tabular}{ll}
\hline Principle & \multicolumn{1}{c}{ Explanation } \\
\hline Relevance & Must be consistent and relevant to decision-making needs of stakeholders. \\
Reliability & Should provide descriptive information about an activity, event, or issue. \\
Complete & Tell both favorable and adverse information, not be value laden. \\
Clarity & Must be simple, easy to interpret, able to be compared over years to highlight trends. \\
Timeliness & Be available regularly to enable trends and indicate change over time. \\
Verifiability & Where possible it should be able to be independently verified. \\
Diversity & A variety of quantitative and qualitative data should be used. \\
\hline
\end{tabular}

Source: Bell and Morse (2008); Griffin (2009); OECD Environment Directorate (2004).

depict different perspectives, should be collected from a range of policy actors in the formal, soft, and corporate sectors (Siddiqi et al., 2009). It is important to remember indicators are only a proxy of performance; they are not comprehensive nor are they a total measure of change. Moreover, a lack of available information and high resource costs (e.g., surveys and interviews) may limit the range and robustness of suitable indicators (Griffin, 2009).

\section{Dimensions of Event Governance}

The dimensions of governance have been widely explored in the policy and public management literature (Agere, 2000; Pierre, 2000; Rhodes, 1997; Savas, 1993; White, 2001; Xavier \& Alfred, 2008). Although this literature remains divided in terms of whether governance leads to "better" outcomes, a broad consensus appears to have emerged in terms of the dimensions by which governance can be deconstructed and better understood. Within the tourism and events literature, and drawing from this broader body of work, six core dimensions of governance are identified as: transparency, rule of law, responsiveness, equitable involvement, structures and processes, and accountability (Dredge, et al., 2010; Ruhanen, Scott, Ritchie, \& Tkaczynski, 2010). These dimensions provide the foundation of values on which indicators are built, although specific measures are not defined (nor are they able to be defined in a generic context as discussed above).

\section{Indicators of Transparency}

Transparency is widely recognized as a core principle of good governance. Transparency means openly sharing information, ensuring that information is directly accessible to those who will be affected by decisions and their enforcement. Transparency means that decision making and implementation are done in a manner that follows rules and regulations. It also means that adequate information is provided in easily understandable forms and media (Parigi, Geeta, \& Kailasam, 2004).

The indicators developed for the transparency dimension (Table 2) reflect the need for transparency at various stages of the policy cycle (see Bridgman \& Davis, 2000). For instance, as a result of increasing delegation of authority to supposedly “independent" event agencies (i.e., state government event corporations) that are at arms' length to government, a lack of transparency often prevails throughout the event bidding and planning process. Therefore, transparency indicators not only identify if actors are aware of bidding processes but also resource allocation processes and procedures. Commercial-in-confidence agreements between governments and event organizers and secrecy around the extent to which public resources are used to bid for, secure, and stage an event can also compound the lack of transparency (Getz, 2009).

The competition to host events may give rise to a situation wherein an event agency will proceed with the project first and attempt to justify it later (Green, Costa, \& Fitzgerald, 2003). As a result, justifications for staging the event may involve glorifying the expected benefits while suppressing potential negative impacts of events (Gursoy \& Kendall, 2006). Thus, transparency indicators incorporate measuring transparency of process, commitment demonstrated by the state, and in the availability of data for public scrutiny. 


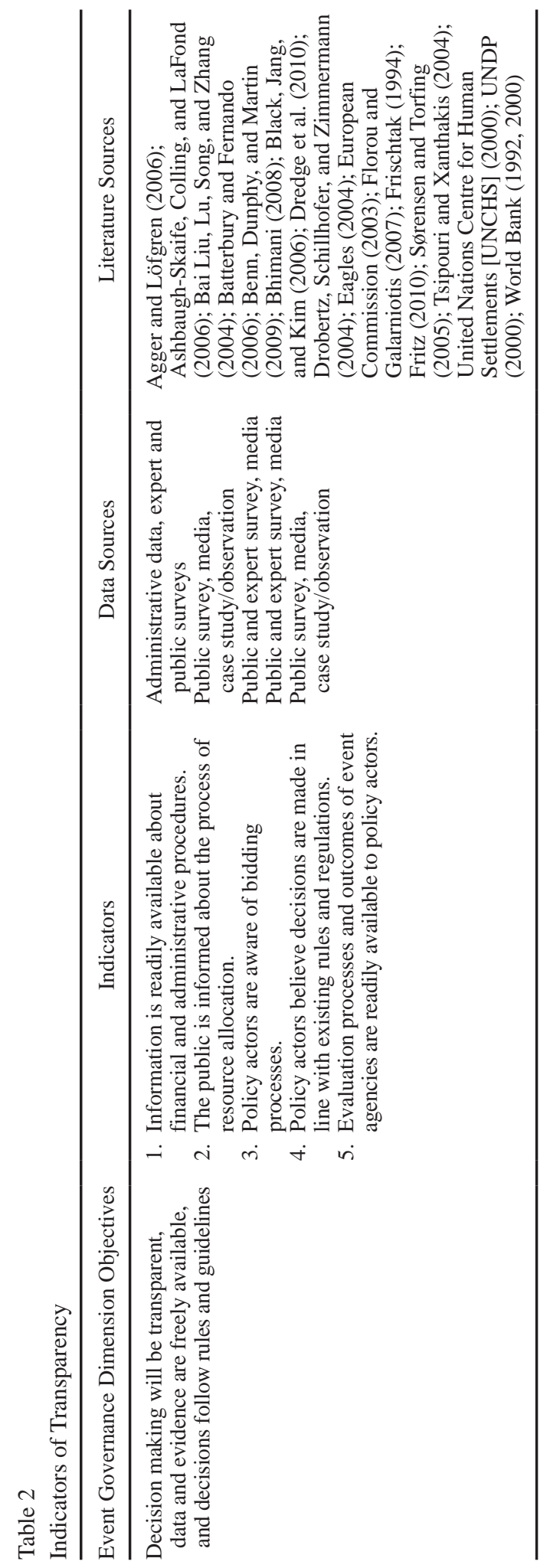

Indicators of Rule of Law

Indicators to measure rule of law in Table 3 provide information about the extent to which event policy makers demonstrate "adherence to established legal frameworks and the embracement of human rights and appropriate ethical standards" (Dredge et al., 2010, p. 13). The rights and expectations embedded within various legal instruments to protect public interests (e.g., environment, community values, etc.) and which have been established over many years are being increasingly challenged in the event policy-making environment (Dredge \& Whitford, 2011). Any action against common rule of law represents a threat to democratic values. For instance, in the formal event policy sector, the rule of law has been challenged by the modification of various existing Acts in the legal system to facilitate the hosting of major events (Dredge et al., 2010; Hall \& Rusher, 2004). Furthermore, special event legislation tends to include clauses that give both the government and event organizers immunity from being challenged before court or administrative reviews for any activities carried out to facilitate the hosting of major events. This leads to concerns that the government and the organizers might not be held responsible for consequences of their decisions regarding the events (Dredge et al., 2010). In essence, indicators for rule of law aim to gauge the extent to which policy actors experience and benefit from the rule of law (Vera Institute of Justice, 2008).

\section{Indicators of Responsiveness}

Responsiveness can be construed differently by different groups of policy actors, and trade-offs in the responsiveness to different policy actors are inevitable. The governance literature suggests that encouraging participation in decision-making processes, which occur in a timely and efficient manner, are important aspects of "good" governance. This is particularly important given that events usually involve a wide number of community and business policy actors, different agencies, and levels of government with varying levels of interest and capacity in decision making. For instance, the event policy cycle is characterized by critical time paths and concentrated spatial dimensions, which in turn place pressure on the various stages of the 


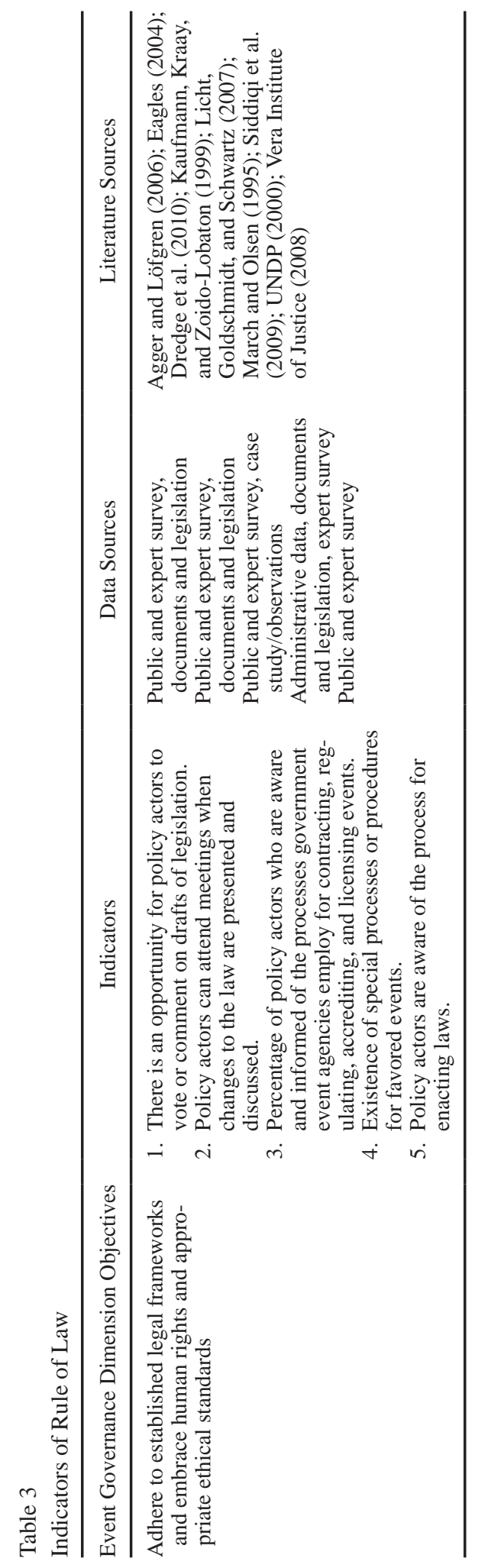

event policy cycle (Bridgman \& Davis, 2000). In the formal and/or soft event policy sector, short timeframes between winning a bid and hosting the event often influence policy makers to opt for quick solutions to realize pending deadlines, instead of adopting the more time-consuming process of identifying and addressing policy problems (Hall \& Rusher, 2004). The indicators for responsiveness (Table 4) have been designed to measure the extent to which policy-making processes take into account the needs and expectations of policy actors in a timely and efficient manner and only after thorough and diligent process has been executed.

\section{Indicators of Equitable Involvement}

The governance literature suggests that encouraging and recognizing diverse and equitable participation in decision-making processes is an important aspect of good governance (Ritchie, 2000; Smith, 2007). Yet the corporatization of event agencies and the contracting out of the planning, management, and evaluation of events has brought about complex layering of public-private sector responsibilities and blurred lines of authority that have been heavily criticized for minimizing local community interests, reducing transparency and accountability of decision-making processes (Andersson \& Getz, 2008; Stokes \& Jago, 2007). Therefore, indicators of equitable involvement (Table 5) have been designed to measure the extent to which policy makers have clearly articulated and implemented strategies for consultation and meaningful participation in decisionmaking processes. A clearer understanding of a community's profile and consultation and participation strategies that respect this profile will help to mitigate conflict among interest groups. Good governance means a community feels included in the event, yet the current political planning process associated with events is often criticized for marginalizing the community's role and allowing "very little input from local residents” (Gursoy \& Kendall, 2006, p. 608). In the formal event policy sector, for example, most of the time, the decision to bid for and host an event is made entirely by the government (Hall, 1989). Similarly, in the corporate event policy sector, in terms of community consultation, Hiller (1998) noted that event organizers were "more interested in marketing the bid to local residents 

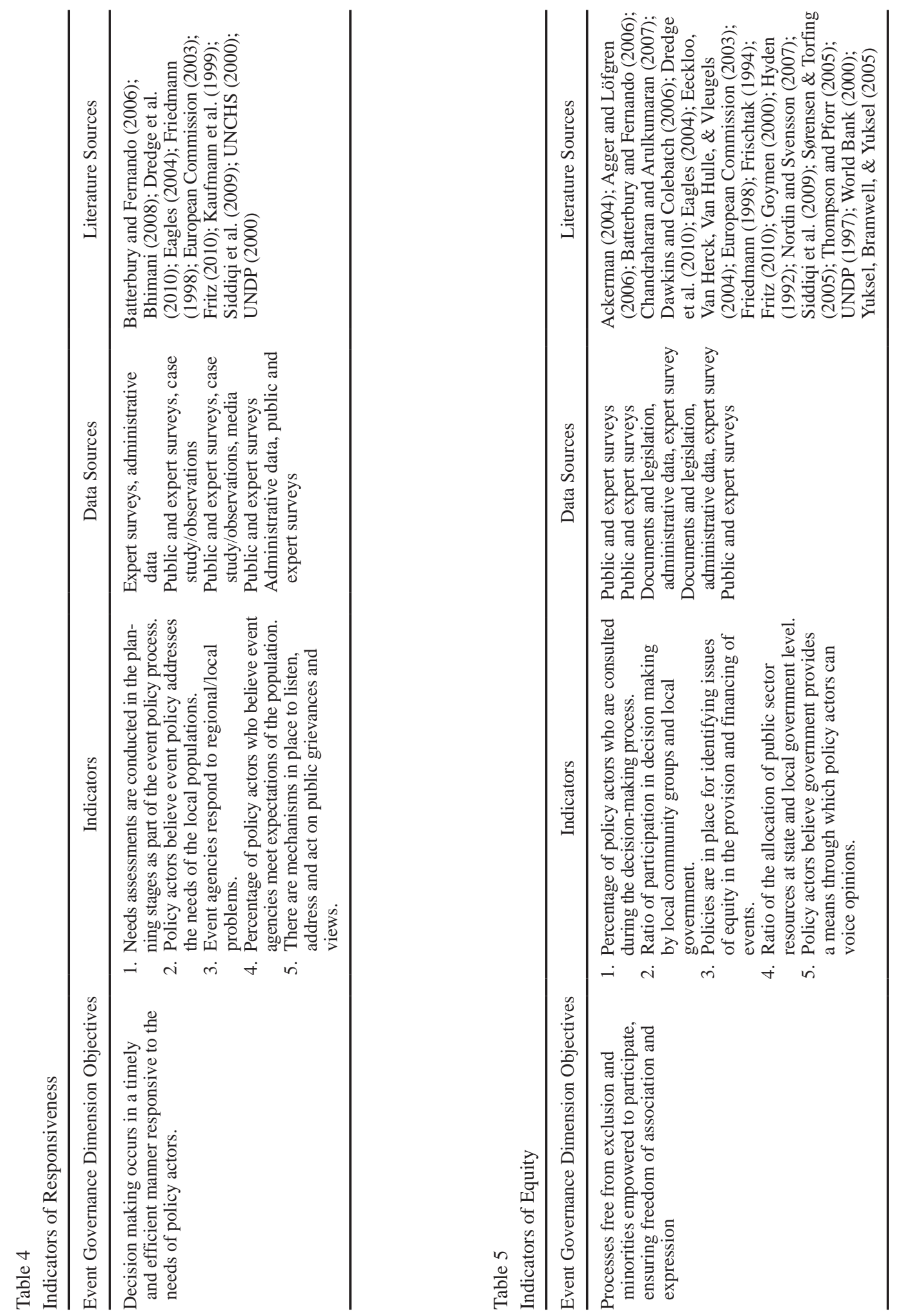
rather than listening to what they had to say” (p. 55). Thus, public participation is often devoid of meaningful discussion of advantages and disadvantages of hosting the event. Rather, governments tend to exercise a form of placation designed to legitimize the decisions of government and developers (Allen et al., 2001) whereas corporations are driven by the bottom line of the budget, often at the expense of the public interest. Both sectors would do well to consider adopting a bottom-up, inclusive approach where strategies for consultation, participation, and information dissemination are clearly and freely articulated in order to promote policy actors becoming advocates, not antagonists, of the event.

\section{Indicators of Structures}

Public policy making takes place within a framework of institutions; therefore, measuring the performance of event governance requires understanding the institutional arrangements and structures in which event policy is made (Hall \& Jenkins, 1995). Policy actors may have membership in different policy networks and their powers, roles, functions, and level of support and interaction may vary within these structures. According to Rhodes (1990, cited in Dredge \& Pforr, 2008), policy networks can develop quasi-institutional structures and rules of conduct and become directly enmeshed in government policy making and implementation such that lines of authority and responsibility are blurred. Furthermore, the structured behavioral patterns of individuals and policy networks may impinge upon government institutions and may affect both the content and outcomes of public policy. For instance, certain structures may prove advantageous to some interests in society and not to others and so the structure of government institutions impacts upon event governance and policy consequences. Additionally, in the formal event policy sector, it is not uncommon that several agencies will assume varying responsibilities for the planning and/or staging of an event. One government agency may become the proponent for an event and another agency within the same government becomes arbiter in the processing of applications for the necessary permissions to stage the event. The indicator set for measuring structures (Table 6) has been designed to identify the

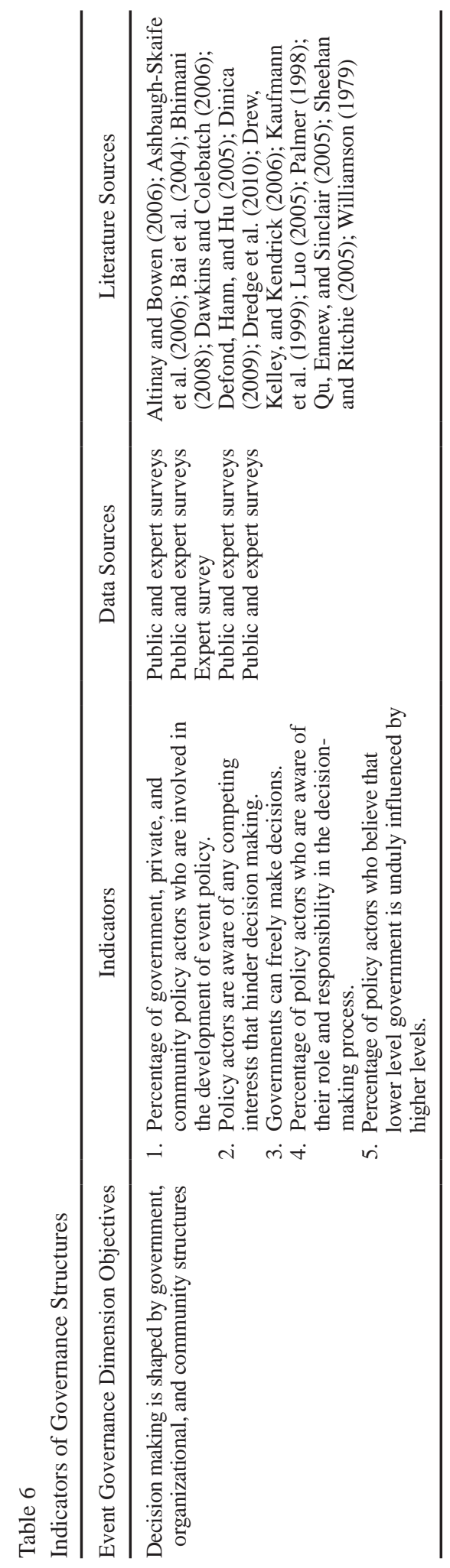


structures in which event governance occurs in order to measure the extent to which decision making is transparent and collaborative and all policy actors, who function with varying levels of interest and capacity, have the opportunity to shape and influence decision-making processes.

\section{Indicators of Accountability}

Accountability is an important aspect of decision making as it generates trust and goodwill between governments and the public (Allen et al., 2011). In the context of government, accountability is defined as the obligation to inform the public about all the actions and decisions, to justify them, and to be responsible for the resulting consequences (Mulgan, 2000). In democratic systems of government there is an expectation that government acts in the public interest yet the system also promotes a discursive approach to defining what exactly those public interests are (Pal \& Maxwell, 2004). As a result, the principle of public interest has been underpinned by the notion that bureaucrats make decisions about what is in the collective public interest, but recent contributions argue that there are multiple publics and diverse public interests (Giddens, 1998; Huntington, 1991; King \& Kendall, 2004). In the event policy sector, events can be handed down (by government) to a host destination based on the presumption that the host community needs and/or wants the event. That is, the event has not been conceptualized in the public interest and too often this leads to community backlash. Therefore, indicators of accountability (Table 7) have been designed to gauge the appropriateness of government decisions and the extent to which the public interest(s) has been considered. Interestingly, accountability can only be secured by keeping decision-making processes transparent and adhering to the rule of law (United Nations Economic and Social Commission for Asia and the Pacific [UNESCAP], 2014).

\section{Discussion}

The complex, fluid, globalized environments in which events operate arguably necessitate the need for effective, efficient, and, importantly, appropriate policy-making processes. We suggest "good governance" is a key to achieving these goals. Thus, the

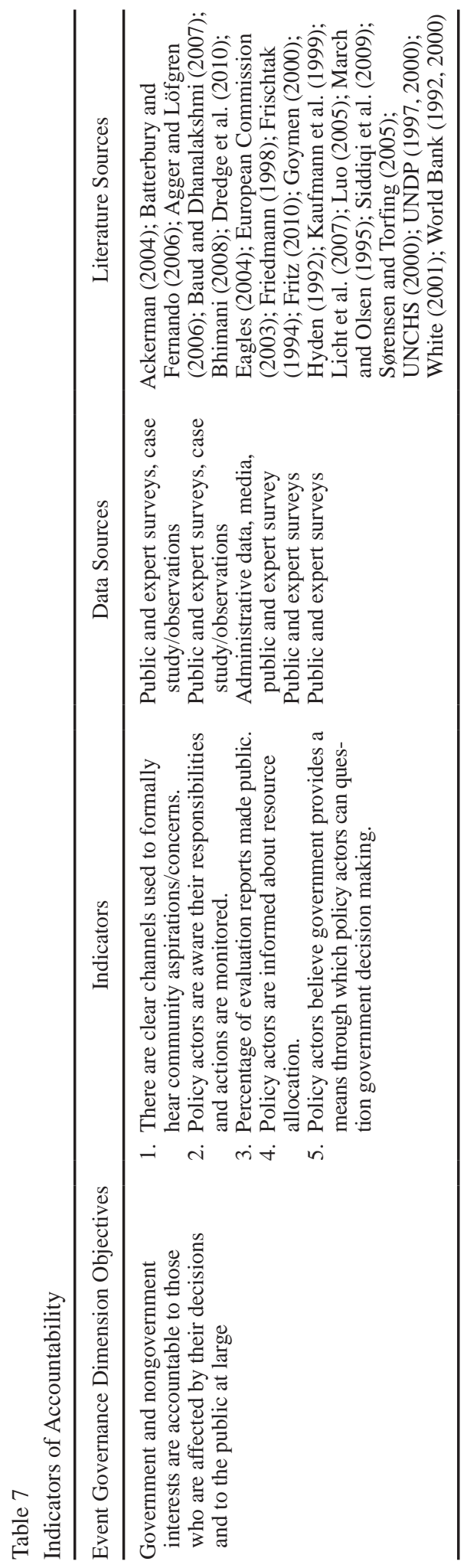


motivation behind the production of event governance indicators has been to address the need for improved methods of monitoring and evaluating event governance performance by developing a framework to guide the measurement of the operationalization of good event governance. According to the Good Governance Advisory Group (2004), "good" governance depends on the actors and groups involved in the policy community, their aspirations and values, and the decisions they make about issues, such as transparency, rule of law, equity and involvement, structures, and power and accountability. The event governance indicators framework provides a useful tool to evaluate how satisfactory event governance is and where it may be improved.

The 30 indicators in Tables 2-7 can be used to assess performance, providing information on whether, and to what degree, progress is being made in relation to event governance. Emulating the methodology of Vera Institute of Justice (2003, 2008) and paying heed to the warnings of G. Williams (2011), the indicators have been fleshed out to measure event governance dimensions from a range and variety of quantitative and qualitative data sources and perspectives. This is particularly pertinent to the complex space of an event, which often involves a large number of policy actors with diverse perceptions and expectations (Dredge et al., 2010).

Although the indicators have been kept simple in order to facilitate practical application for decision makers (Morrissey, O’Regan, \& Moles, 2006), they have met a certain number of quality criteria including relevance and usefulness for users; robustness, reliability, and precision; quality and availability of the data; comparability; legibility; and transparency. The range and robustness of the indicators may be limited by a lack of available information and high resource costs (e.g., data collection) (Griffin, 2009). Therefore, although the indicators may be used to (1) assess progress toward an objective, (2) measure performance, and (3) track progress in the implementation of a program or policy (Parsons et al., 2008), it is necessary to realize that the indicators are only a proxy of performance; they are not comprehensive nor are they a total measure of change. Furthermore, it is important to note here that the aforementioned indicators of event governance are still blunt. There will never be a perfect set of indicators, reflecting the subtle mix of aspects characterizing event governance systems; therefore, the best strategy is to use a variety of indicators (Bovaird \& Löffler, 2003). Moreover, the importance of the indicators can be expected to vary between contexts and over time and it is likely that different policy actors in the complex environment of events will have differing views on what they mean in practice. Nevertheless, the set of indicators to measure the performance of event governance will provide a means to assess event policymaking over time, from local to international levels to facilitate the effective operationalization of event governance (Bovaird \& Löffler, 2003).

\section{Conclusions}

The overall aim of this conceptual article was to develop a set of indicators that can be used to evaluate the effectiveness of event governance arrangements. Public-private event governance will continue to grow as governments seek to facilitate economic development through private sector initiatives. We have presented an indicators framework for event governance, but argue that it should continue to evolve; indicators should be added and refined in a process of testing and iteration. This line of inquiry would assist in achieving more effective event governance, as greater attention could be paid to the nature and quality of policy actor participation in decision making about the event; by respecting current rule of law and working within these frameworks; and by demonstrating real commitment to public interest, transparency, accountability, and a responsiveness to local issues that goes beyond rhetoric.

Although we recognize that the term "good governance" is problematic in that there can be no overall set of indicators independent of context, a set of indicators appropriately negotiated at the outset of an event planning process can become a crucial tool in managing stakeholder expectations. Here, the importance of empirically testing and further refining the indicators presented in this article is emphasized. The need for further research is particularly pertinent in light of a recent special issue on indicators and certification [see Tourism Recreation Research 36(3)], which advises caution 
as indicators and associated evaluation frameworks are largely an artifact of neoliberal public management in market economies and they do not necessarily translate well to developing countries or other cultural contexts. Importantly then, future research should heed the advice of G. Williams (2011) pertaining to good practice tips for developing governance indicators and (1) acknowledge statistical uncertainty inherent in governance indicators and potential sources of bias in the types of data used; (2) include subjective indicators based on perceptions surveys and expert judgments to capture less tangible aspects of governance, and (3) be alert to the normative assumptions behind governance indicators, and actively question whether they are appropriate to the particular event context.

\section{References}

Ackerman, J. (2004). Co-governance for accountability: Beyond “exit” and "voice.” World Development, 32(3), 447-463.

Agere, S. (2000). Promoting good governance: Principles, practices and perspectives. London: Commonwealth Secretariat.

Agger, A., \& Löfgren, K. (2006). How democratic are networks based on citizen involvement? Roskilde, Denmark: Centre for Democratic Network Governance.

Ali-Knight, J., \& Robertson, M. (2004). Introduction to arts, culture and leisure. In I. Yeoman, M. Robertson, J. Ali-Knight, S. Drummond, \& U. McMahon-Beatte (Eds.), Festivals and events management (pp. 217-231). Oxford: Elsevier.

Allen, J., O’Toole, W., Harris, R., \& McDonnell, I. (2001). Festival and special event management (5th ed.). Brisbane: John Wiley \& Sons Australia.

Altinay, L., \& Bowen, D. (2006). Politics and tourism interface. The case of Cyprus. Annals of Tourism Research, 33(4), 939-956.

Andersson, T., \& Getz, D. (2008). Sustainable festivals: On becoming an institution. Event Management, 12(1), 1-17.

Arndt, C., \& Oman, C. (2006). Uses and abuses of governance indicators. Paris: OECD Development Centre Studies.

Ashbaugh-Skaife, H., Collins, D. W., \& LaFond, R. (2006). The effects of corporate governance on firms' corporate ratings. Journal of Accounting and Economics, 42(1-2), 203-243.

Bai, C. E., Liu, Q., Lu, J. S., Song, F. M., \& Zhang, J. (2004). Corporate governance and market valuation in China. Journal of Comparative Economics, 32(4), 599-616.

Batterbury, S. P. J., \& Fernando, J. L. (2006). Rescaling governance and the impacts of political and environmental decentralization: An introduction. World Development, 34(11), 1851-1863.
Baud, I., \& Dhanalakshmi, R. (2007). Governance in urban environmental management: Comparing accountability and performance in multi-stakeholder arrangements in South India. Cities, 24, 133-137.

Beaumont, N., \& Dredge, D. (2010). Local tourism governance: A comparison of three network approaches. Journal of Sustainable Tourism, 18(1), 7-28.

Bell, S., \& Morse, S. (2008). Sustainability indicators: Measuring the immeasurable? London: Earthscan.

Benn, S., Dunphy, D., \& Martin, A. (2009). Governance of environmental risk: New approaches to managing stakeholder involvement. Journal of Environmental Management, 90(4), 1567-1575.

Bhimani, A. (2008). Risk management, corporate governance and management accounting: Emerging interdependencies. Management Accounting Research, 20, 2-5.

Black, B. S., Jang, H., \& Kim, W. (2006). Predicting firms’ corporate governance choices: Evidence from Korea. Journal of Corporate Finance, 12(3), 660-691.

Bovaird, T., \& Löffler, E. (2003). Evaluating the quality of public governance: Indicators, models and methodologies. International Review of Administrative Sciences, 69, 313-328.

Bramwell, B. (2011). Governance, the state and sustainable tourism: A political economy approach. Journal of Sustainable Tourism, 19(4-5), 459-477.

Bramwell, B., \& Pomfret, G. (2007). Planning for lake and lake shore tourism: Complexity, coordination and adaptation. Anatolia: An International Journal of Tourism and Hospitality Research, 18(1), 43-66.

Bramwell, R. (1997). Strategic planning before and after a mega-event. The Hotur: Quarterly Journal of the Pakistan Institute of Tourism \& Hotel Management, 18, 167-176.

Bridgman, P., \& Davis, G. (2000). Australian policy handbook (2nd ed.). Sydney: Allen \& Unwin.

Burns, D. (2000). Can local democracy survive governance? Urban Studies, 37(5-6), 963-973.

Burns, J. P. A., \& Mules, T. J. (1986). A framework for the analysis of major special events. In J. P. A. Burns, J. H. Hatch, \& T. J. Mules (Eds.), The Adelaide Grand Prix. Papers of the Australian Travel Research Workshop: The impact and marketing of special events (pp. 1-14). Adelaide, Australia: Australian Standing Committee on Tourism, Mount Buffalo.

Chandraharan, E., \& Arulkumaran, S. (2007). Clinical governance. Obstetrics, Gynecology \& Reproductive Medicine, 17, 222-224.

Crozier, M. (2008). Listening, learning, steering: New governance, communication and interactive policy formation. Policy \& Politics, 36(1), 3-19.

Dawkins, J., \& Colebatch, H. K. (2006). Governing through institutionalised networks: The governance of Sydney Harbour. Land Use Policy, 23, 333-343.

Defond, M. L., Hann, R. N., \& Hu, X. (2005). Does the market value financial expertise on audit committees or boards of directors? Journal of Accounting Research, 43(2), 153-193. 
Dinica, V. (2009). Governance for sustainable tourism: A comparison of international and Dutch visions. Journal of Sustainable Tourism, 17(5), 583-603.

Dredge, D., Ford, E., Lamont, M., Phi, G., Whitford, M., \& Wynn-Moylan, P. (2010). Event governance: The rhetoric and reality of the World Rally Championship, Northern Rivers, NSW. Paper presented at CAUTHE 2010: Challenge the Limits, University of Tasmania, Hobart.

Dredge, D., \& Jenkins, J. (2007). Tourism planning and policy. Milton, Australia: John Wiley \& Sons.

Dredge, D., \& Pforr, C. (2008). Tourism policy networks and tourism governance. In N. Scott, R. Baggio, \& C. Cooper (Eds.), Network analysis and tourism (pp. 58-78). Clevedon, UK: Channel View Publications.

Dredge, D., \& Whitford, M. (2011). Event tourism governance and the public sphere. Journal of Sustainable Tourism, 19(4-5), 479-499.

Drew, S. A., Kelley, P. C., \& Kendrick, T. (2006). CLASS: Five elements of corporate governance to manage strategic risk. Business Horizons, 49(2), 127-138.

Drobertz, W., Schillhofer, A., \& Zimmermann, A. (2004). Corporate governance and expected stock returns: Evidence from Germany. European Financial Management, 10(2), 267-293.

Duffy, R. (2006). Global environmental governance and the politics of ecotourism in Madagascar. Journal of Ecotourism, 5(1/2), 128-144.

Dwyer, L., Forsyth, P., \& Spurr, R. (2005). Estimating the impacts of special events on an economy. Journal of Travel Research, 43(4), 351-359.

Eagles, P. F. J. (2004). Governance of recreation and tourism partnerships in parks and protected areas. Journal of Sustainable Tourism, 17, 231-248.

Eagles, P., Havitz, M., McCutcheon, B., Buteau-Duitschaever, W., \& Glover, T. (2010). The perceived implications of an outsourcing model on governance within British Columbia Provincial parks in Canada: A quantitative study. Environmental Management, 45(6), 1244-1256.

Eeckloo, K., Van Herck, G., Van Hulle, C., \& Vleugels, A. (2004). From corporate governance to hospital governance. Authority, transparency and accountability of Belgian non-profit hospitals' board and management. Health Policy, 68, 1-15.

European Commission. (2003). Handbook on promoting good governance in EC development and co-operation. Brussels: Author.

Faulkner, B. (1993). Evaluating the tourism impacts of hallmark events (occasional paper No. 16). Canberra: Bureau of Tourism Research.

Florou, A., \& Galarniotis, A. (2007). Benchmarking Greek corporate governance against different standards. Corporate Governance, 15(5), 979-998.

Foley, M., McGillivray, D., \& McPherson, G. (2009). Policy, politics and sustainable events. In R. Raj \& J. Musgrave (Eds.), Event management and sustainability (pp. 13-21). Wallingford, UK: CABI.

Foley, M., McGillivray, D., \& McPherson, G. (2011). Event policy: From theory to strategy. London: Routledge.
Francois, R. (2009). World governance index: Why should world governance be evaluated, and for what purpose? Retrieved from http://www.world-governance.org/spip. php?article469

Fredline, E., \& Faulkner, B. (2001). Variations in residents' perceptions of major motorsports events: Why residents perceive the impacts differently. Event Management, 7, 115-125.

Fredline, E., Raybould, M., Jago, L., \& Deery, M. (2005). Triple bottom line event evaluation: A proposed framework for holistic event evaluation. In J. Allen (Ed.), The impacts of events: Proceedings of International Events Conference (pp. 2-15). Sydney, Australia: Australian Centre for Event Management.

Friedmann, J. (1998). The new political economy of planning: The rise of civil society. In J. Friedmann (Ed.), Cities for citizens: Planning and the rise of civil society in a global age (pp. 3-15). Chichester, UK: Wiley.

Frischtak, L. L. (1994). Governance capacity and economic reforms in developing countries. Washington, DC: World Bank.

Fritz, J. S. (2010). Towards a 'new form of governance' in science-policy relations in the European Maritime Policy. Marine Policy, 34(1), 1-6.

Gamage, A., \& Higgs, B. (1996). Economic of venue selection for the special sporting events: With special reference to the 1996 Melbourne Grand Prix. Asia Pacific Journal of Tourism Research, 1(2), 15-28.

Getz, D. (2000). Developing a research agenda for the events management field. In J. Allen, R. Harris, L. K. Jago, \& A. J. Veal (Eds.), Events Beyond 2000: Setting the Agenda. Proceedings of Conference on Event Evaluation, Research and Education (pp. 10-21). Sydney: Australian Centre for Event Management, School of Leisure, Sport and Tourism, University of Technology.

Getz, D. (2008). Event tourism: Definition, evolution and research. Tourism Management, 29(3), 403-428.

Getz, D. (2009). Policy for sustainable and responsible festivals and events: Institutionalization of a new paradigm. Journal of Policy Research in Tourism, Leisure and Events, 1(1), 61-78.

Getz, D., \& Andersson, T. (2008). Sustainable festivals: On becoming an institution. Event Management, 12(1), 1-17.

Gibson-Graham, J. K. (2006). A postcapitalist politics. Minneapolis \& London: University of Minnesota Press.

Giddens, A. (1998). The third way: The renewal of social democracy. Oxford: Polity.

Giddens, A. (2000). The third way and its critics. Malden, MA: Blackwell Publishers.

Good Governance Advisory Group. (2004). Good governance guide: The principles of good government within local government. Melbourne: The Municipal Association of Victoria.

Gotham, K. (2002). Marketing Mardi Gras: Commodification, spectacle and the political economy of tourism in New Orleans. Urban Studies, 39(10), 1735-1756.

Goymen, K. (2000). Tourism and governance in Turkey. Annals of Tourism Research, 27(4), 1025-1048. 
Green, B. C., Costa, C. A., \& Fitzgerald, M. P. (2003). Marketing the host city: Analyzing exposure generated by a sport event. International Journal of Sports Marketing \& Sponsorship, 4, 335-353.

Griffin, K. A. (2009). Indicators and tools for sustainable event management. In R. Raj \& J. Musgrave (Eds.), Event management and sustainability (pp. 43-55). Wallingford, UK: CABI.

Gursoy, D., \& Kendall, K. (2006). Hosting mega events: Modeling locals' support. Annals of Tourism Research, 33, 603-623.

Hall, C. M. (1989). Special interest travel: A prime force in the expansion of tourism? In R. Welch (Ed.), Geography in action (pp. 81-89). Dunedin, New Zealand: University of Otago.

Hall, C. M. (2011). A typology of governance and its implications for tourism policy analysis. Journal of Sustainable Tourism, 19(4-5), 437-457.

Hall, C. M., \& Jenkins, J. (1995). Tourism and public policy. London: Routledge.

Hall, C. M., \& Rusher, K. (2004). Risky lifestyles? Entrepreneurial characteristics of the New Zealand bed and breakfast sector. In R. Thomas (Ed.), Small firms in tourism. International perspectives (pp. 83-97). New York: Elsevier.

Harris, R. (2005). Approaches to community engagement by public events. In J. Allen (Ed.), The impacts of events: Proceedings of International Events Conference (pp. 286-300). Sydney, Australia: Australian Centre for Event Management.

Hede, A. (2007). Managing special events in the new era of the triple bottom line. Event Management, 11, 13-22.

Hezri, A. A., \& Dovers, S. R. (2006). Sustainability indicators, policy and governance: Issues for ecological economics. Ecological Economics, 60(1), 86-99.

Higgins-Desboilles, F. (2006). More than an "industry": The forgotten power of tourism as a social force. Tourism Management, 27, 1192-1208.

Hiller, H. H. (1998). Assessing the impact of mega-events: A linkage model. Current Issues in Tourism, 1, 47-57.

Hirst, P. (2000). Democracy and governance. In J. Pierre (Ed.), Debating governance. Oxford: Oxford University Press.

Huntington, S. (1991). The third wave. Norman, OK: University of Oklahoma Press.

Hyden, G. (1992). Governance and the study of politics. In G. Hyden \& M. Bratton (Eds.), Governance and politics in Africa (pp. 1-26). Boulder, CO: Lynne Rienner Publishers.

Kaufmann, D., Kraay, A., \& Zoido-Lobaton, P. (1999). Governance matters. Washington, DC: World Bank.

King, R., \& Kendall, G. P. (2004). The state, democracy and globalization. Basingstoke, UK: Palgrave Macmillan.

Klijn, E., \& Skelcher, C. (2007). Democracy and governance networks: Compatible or not. Public Administration, 85(3), 587-608.

Ladeur, K. H. (2004). Public governance in the age of globalization. Hants, UK: Ashgate Publishing.
Licht, A. N., Goldschmidt, C., \& Schwartz, S. H. (2007). Culture rule: The foundations of the rule of law and other norms of governance. Journal of Comparative Economics, 35(4), 659-688.

Lowes, M. (2004). Neoliberal power politics and the controversial siting of the Australian Grand Prix motorsport event in an urban park. Leisure and Society, 27(1), 69-88.

Luo, Y. (2005). Corporate governance and accountability in multinational enterprises: Concepts and agenda. Journal of International Management, 11(1), 1-18.

March, J. G., \& Olsen, J. P. (1995). Democratic governance. New York: Free Press.

Marsh, I. (2002). Governance in Australia: Emerging issues and choices. Australian Journal of Public Administration, 61(2), 3-9.

Maurseth, P. B. (2008). Governance indicators: A guide (NUPI Working Paper No. 754). Oslo, Norway: NUPI.

McSweeney, B. (2006). Are we living in a post-bureaucratic epoch? Journal of Organizational Change Management, 19(1), 22-37.

Morrissey, J., O’Regan, B., \& Moles, R. (2006). Development of indicator and indices for the evaluation of the sustainability of Irish settlements and regional settlement patterns. In Proceedings of Environ 2006, University College Dublin (pp. 17-22). Cork: Environmental Sciences Association of Ireland.

Mowforth, M., \& Munt, I. (2003). Tourism and sustainability: Development and new tourism in the Third World (2nd ed.). London \& New York: Routledge.

Mulgan, R. (2000). Accountability: An ever-expanding concept? Public Administration, 78, 555-573.

Nordin, S., \& Svensson, B. (2007). Innovative destination governance: The Swedish ski resort of Are. Entrepreneurship and Innovation, 8, 53-66.

Organisation for Economic Co-operation and Development Environment Directorate. (2004). Using the pressurestate-response model to develop indicators of sustainability. Retrieved from http://www.fao.org/ag/againfo/ programmes/en/lead/toolbox/Refer/EnvIndi.htm

O’Sullivan, D., \& Jackson, M. (2002). Festival tourism: A contributor to sustainable local economic development? Journal of Sustainable Tourism, 10(4), 325-342.

Pal, L. A., \& Maxwell, J. (2004). Assessing the public interest in the 21st century: A framework. Ottawa, Canada: Canadian Policy Research Network.

Palmer, A. (1998). Evaluating the governance style of marketing groups. Annals of Tourism Research, 25, 185-201.

Parigi, K., Geeta, P., \& Kailasam, R. (2004). Ushering in transparency for good governance. Retrieved from www. cgg.gov.in/workingpapers/Ushering_in_Transparency. pdf

Parsons, J., Thornton, M., Bang, H. E., Estep, B., Williams, K., \& Weiner, N. (2008). Developing indicators to measure the rule of law: A global approach: A report to the World Justice Project. New York: Vera Institute of Justice and Altus Global Alliance.

Pierre, J. (2000). Debating governance. New York: Oxford University Press. 
Pugh, C., \& Wood, E. H. (2004). The strategic use of events within local government: A study of London Borough Councils. Event Management, 9(1), 61-71.

Qu, R., Ennew, C., \& Sinclair, M. T. (2005). The impact of regulation and ownership structure on market orientation in the tourism industry in China. Tourism Management, 26(6), 939-950.

Reid, G. (2006). The politics of city imaging: A case study of the MTV Europe Music Awards Edinburgh 03. Event Management, 10(1), 35-46.

Reid, S., \& Arcodia, C. (2002). Understanding the role of the stakeholder in event management. Paper presented at Events and place making. UTS Business: Event research conference, UTS Australian Centre for Event Management, University of Technology, in association with CRC in Sustainable Tourism, Sydney, Australia.

Rhodes, R. A. W. (1990). Policy networks: A British perspective. Journal of Theoretical Politics, 2, 293-317.

Rhodes, R. A. W. (1997). Understanding governance: Policy networks, governance, reflexitivity and accountability. Buckingham, UK: Open University Press.

Ritchie J. R. B. (1984). Assessing the impact of hallmark events: Conceptual and research issues. Journal of Travel Research, 23(1), 2-11.

Ritchie, J. R. B. (2000). Turning 16 days into 16 years through Olympic legacies. Event Management, 6(3), 155-165.

Ruhanen, R., Scott, N., Ritchie, B., \& Tkaczynski, A. (2010). Governance: A review and synthesis of the literature. Tourism Review, 65(4), 4-16.

Savas, E. S. (1993). Catalytic government: Steering rather than rowing. In D. Osborne \& T. Gaebler (Eds.), Reinventing government. New York: A Plume Book.

Sheehan, L. R., \& Ritchie, J. R. B. (2005). Destination stakeholders: Exploring identity and salience. Annals of Tourism Research, 32(3), 711-734.

Sherwood, P. (2007). A triple bottom line evaluation of the impact of special events: The development of indicators. Unpublished doctoral dissertation, Victoria University.

Siddiqi, S., Masud, T. I., Nishtar, S., Peters, D. H., Sabri, B., Bile, K. M., et al. (2009). Framework for assessing governance of the health system in developing countries: Gateway to good governance. Health Policy, 90(1), 13-25.

Smith, A. (2007). Large-scale events and sustainable urban regeneration: Key principles for host cities. Journal of Urban Regeneration and Renewal, 1(2), 178-190.

Sørensen, E., \& Torfing, J. (2005). Network governance and post-liberal democracy. Administrative Theory \& Praxis, 27(2), 197-237.

Stokes, R. (2006). Network-based strategy making for events tourism. European Journal of Marketing, 40(5-6), $682-695$.

Stokes, R. (2008). Tourism strategy making: Insights to the events tourism domain. Tourism Management, 29(2), 252-262.

Stokes, R., \& Jago, L. (2007). Australia’s public sector environment for shaping event tourism strategy. International Journal of Event Management Research, 3(1), 42-53.
Suggett, D., \& Goodsir, B. (2002). Triple bottom line measurement and reporting in Australia. Making it tangible. Melbourne: The Allen Consulting Group.

Teriman, S., Yigitcanlar, T., \& Mayere, S. (2009). Urban sustainability and growth management in south-east Asian city-regions: The case of Kuala Lumpur and Hong Kong. Planning Malaysia: Journal of the Malaysian Institute of Planners, 7(1), 47-68.

Thomas, R., \& Wood, E. H. (2004). Event-based tourism: A survey of local authority strategies in the UK. Local Governance, 29(2), 127-136.

Thompson, G., \& Pforr, C. (2005). Policy networks and good governance: A discussion. Perth, Australia: School of Management, Curtin University of Technology.

Tsipouri, L., \& Xanthakis, M. (2004). Can corporate be rated? Ideas based on the Greek experience, corporate governance. An International Review, 12(1), 16-28.

UK Department for Communities and Local Government. (2006). Good practice guide on planning for tourism. London: Author.

United Nations Centre for Human Settlements. (2000). Principles of good urban governance. New York: Author.

United Nations Development Programme. (1997). Governance for sustainable human development: A policy document. New York: Author.

United Nations Development Programme. (2000). The urban governance initiative. Kuala Lumpur: Author.

United Nations Development Programme. (2007). Governance Indicators: A user's guide. Retrieved from http://www. undg.org/docs/11652/UNDP-Governance-IndicatorsGuide-(2007).pdf

United Nations Economic and Social Commission for Asia and the Pacific. (2014). What is good governance? Retrieved from http://www.unescap.org/sites/default/files/goodgovernance.pdf

Vera Institute of Justice. (2003). Measuring progress toward safety and justice: A global guide to the design of performance indicators across the justice sector (summary paper). New York: Author.

Vera Institute of Justice. (2008). Developing indicators to measure the rule of law: A global approach: A report to the World Justice Project. New York: Vera Institute of Justice and Altus Global Alliance.

Warren, I. (2002). Governance, protest and sport: An Australian perspective. Entertainment Law, 1(1), 67-94.

Weed, M. (2003). Why the two won't tango! Explaining the lack of integrated policies for sport and tourism in the UK. Journal of Sport Management, 17(3), 258-283.

Weed, M. (2006). Sports tourism research 2000-2004: A systematic review of knowledge and a meta-evaluation of methods. Journal of Sport and Tourism, 11(1), 5-30.

White, L. (2001). Effective governance through complexity thinking and management science. System Research and Behavioral Science, 18, 241-257.

Whitford, M. (2004a). Regional development through domestic and tourist event policies: Gold Coast and Brisbane, 1974-2003. UNLV Journal of Hospitality, Tourism and Leisure Science, 1, 1-24. 
Whitford, M. (2004b). Event public policy development in the northern sub-regional organisation of councils, Queensland, Australia: Rhetoric or realisation? Journal of Convention and Event Tourism, 6(3), 81-99.

Whitford, M. (2005). Event public policy and regional development in South East Queensland. In J. Allen (Ed.), The impacts of events: Proceedings of International Events Conference (pp. 405-428). Sydney, Australia: Australian Centre for Event Management.

Whitford, M. (2009). Oaxaca's indigenous Guelaguetza festival: Not all that glistens is gold. Event Management, 12(3-4), 143-161.

Williams, G. (2011). Policy practice brief 6-What makes a good governance indicator? Retrieved August 15, 2011, from http://www.thepolicypractice.com/papersdetails.asp? code $=17$

Williams, A., \& Siddique, A. (2008). The use (and abuse) of governance indicators in economics: A review. Economics of Governance, 9(2), 131-175.
Williamson, O. E. (1979). Transaction-cost economics: The governance of contractual relations. Journal of Law and Economics, 22, 233-261.

World Bank. (1992). Governance and development. Washington, DC: Author.

World Bank. (2000). Attacking poverty. World development report. Washington, DC: Author.

Xavier, M., \& Alfred, V. (2008). The changing role of governments and the emergence of the relational state. Corporate Governance, 8(4), 389.

Yaghmour, S. (2008). Interorganizational collaboration characteristics and outcomes: A case study of the Jeddah Festival. Unpublished thesis, School of Tourism, The University of Queensland, Brisbane.

Yuksel, F., Bramwell, B., \& Yuksel, A. (2005). Centralized and decentralized tourism governance in Turkey. Annals of Tourism Research, 32(4), 859-886. 